\title{
Governance Perspectives of Human Security in Africa
}

\author{
Kwesi Aning and Ernest Ansah Lartey
}

\begin{abstract}
Human security should not be considered as a mere academic rhetoric-it is, in fact, a political tool aimed at transforming individuals from conditions of exploitation and domination to that of political participation and accountability. This paper adopts political governance perspectives to analyze human security in Africa. It argues that without accountable democratic governance, the expressed objectives of human security would be difficult to achieve in Africa. By this focus, the paper adopts a broader view of human security, satisfying both the governance and development prerequisites of the concept, which has underpinned [in] security in Africa. The overall estimation of human security in Africa is that only a marginal improvement has been made in the region, especially over the last decade.
\end{abstract}

Keywords accountable governance, Africa, democracy, human security, security sector governance

\section{Introduction}

Since the early 1990s, the term 'human security' has been used to signal a shift in the ways security is viewed across the world. The concept was meant to demonstrate a "paradigm" shift from the traditional concept of security, which predominantly emphasized military defense of state interests and territorial boundaries (Paris 2001). This traditional notion of security was the type which shaped many national security policies and architectures, especially during the cold war period. However, while the traditional security or state-centric security was meant to strengthen and to stabilize state governance institutions and to ensure state monopoly over the means of force and violence (Civic and Miklaucic 2011), it nonetheless led to the creation of 'regime security', which-at the very best-created and spread authoritarian rule across many parts of Africa.

As argued by Luckham (2003), part of the reason is that the security structures, which emerged following statebuilding at independence, still reflected 
the repressive tendencies characterized by colonial rule. In many instances across Africa, these colonial legacies have persisted and the search for ways to reduce and replace those tendencies still remains a challenge. Especially within the Coldwar period, it was thought to be necessary that the post-independence governance process required a certain political posture which had to be extensively sensitive to the external ideological influences. This undermined political accountability at home, especially in the ways state institutions were built to protect ruling regimes as opposed to the state (Bryden and Fairlie 2015). Without proper political accountability and limited participation in governance and security, control and access to the political center has become a violent struggle, thus exposing the insecurity dilemma which most states in Africa exhibit today. Weak state institutions - as a result of their less accountability reforms-cannot be addressed without a shift of the security discourse from regime-based to people-centered.

Majority of African population are still at risk as global health threats, frequent and intense natural disasters, spiraling conflict, violent extremism, terrorism and related humanitarian crises such as forced displacement of people threaten to negate the large measure of development progress made in recent decades. In spite of the fact that a good spectrum of these humanitarian crises is naturally-based, unsustainable man-made exploitation of the natural environment has also led to this current level of global risks and vulnerabilities (see UN 2015, para. 14). Also, and more importantly, it has to be argued that a combination of state and non-state actors' proliferation of armed groups and violence has underpinned this risk; often caused by violations of human rights and rule of law, as well as the inability to hold perpetrators to account (Ndiaye 2010).

The customary security and justice systems, which in several cases predate the modern state institutions, increasingly serve as alternative avenues for the vast majority of African population (see Aning and Aubyn 2018; Jaye 2018). However, inherent in these alternative security systems, are as argued by M'CormackHale (2018) certain beliefs and practices which are thought to be inimical to the survival, safety and wellbeing of the population, especially the vulnerable group such as women and children.

Similarly, in spite of all the plaudits about increasing economic growth in the region, poverty, hunger, and diseases continue to expose weaknesses in the development paradigms and policies of most African countries (Cheru 2007). Majority of the population still live on less than a dollar a day, and are unable to enjoy basic necessities such as food, literacy, health, shelter, sanitation and quality climate (UN 2015). By way of seeking to bridge the security-development gap, the United Nations (UN 2015) implementation of the 2030 Agenda for Sustainable Development, which spelt out broad targets to among others lift populations out of poverty, protect the planet and ensure that all people enjoy peace and prosperity, remains a crucial emphasis for deepening and expanding the security 
concept.

This paper looks at human security from the perspective of political governance in Africa. It essentially argues that without accountable democratic governance, the expressed objectives of human security (namely, freedom from fear and freedom from want) would be difficult to achieve in Africa. In this context, democratic governance, which connotes participation and ownership of political decisions and outcomes (see Haynes 2006), is seen as a tool to transform both the root causes of insecurity (include structural issues such as poverty, inequality, health pandemics and environmental hazards), as well as the effects of insecurity (namely conflicts, violent extremism, and inadequate respect for the rule of law and human rights).

The paper extensively draws on two sets of research reports, namely Freedom House Report (Freedom House 2019) and Ibrahim Index of African Governance (IIAG 2018) to discuss the topic of human security in Africa. While the Freedom House Report disaggregated its analysis, covering sub-Saharan Africa vis-à-vis the rest of the regions in the world, the Ibrahim Index of African Governance report focuses entirely on Africa. Such comparison allows for deeper reflections, and contextual operationalization of human security in this paper. This means that even though reference is made to the term sub-Saharan Africa in the text a few times, it does not limit the scope of the discussion on human security in Africa. The indicators used in measuring human security in this paper include: (1) safety and rule of law; (2) participation and human rights; (3) sustainable economic opportunity; and, (4) human development as adopted from the IIAG 2018. The overall estimation of human security in Africa, as argued by the paper, is that only a marginal improvement has been made in the region, especially over the last decade. This is because despite the fact that there are now more countries claiming to be democratic than was seen in the early 1990s, there are still governance deficits in the form of violent political contestations and the abuse of the rule of law in some countries which continue to undermine the continent's human security.

\section{Explaining Human Security}

In contrast to human security (which will be explained in detail in a little while), state security on the one hand, depicts the condition in which institutions, processes and structures of the state (especially that of the state security institutions) continue to be governed and shaped by the rule of law irrespective of the composition of the ruling elites. Regime security on the other hand is often concerned with the condition in which the governing elites are protected despite violent challenges to their rule (see Jackson 2007). This becomes possible when the entire national security policy architecture is shaped purposely to safeguard 
the regime from internal opposition (Bryden, N’Diaye, and Oloniskin 2008). In Africa, the focus on and dominance of regime protection in the past has made the two concepts somewhat indistinguishable. As a result, African countries rather tend to exhibit more internal state weakness and fragility than from the external sphere (ibid.). Thus, these conditions provide the ideal impetus for democratic processes to be coupled with security and defense sector reforms, which will incorporate the respect for human rights and the rule of law.

From the perspective of the United Nations, the concept of human security has become even more pertinent today as living conditions of the vast majority of the world's population continue to worsen. By 2015, in spite of the tremendous human development progress, the UN was still concerned about the deteriorating humanitarian trend and articulated that:

Billions of our citizens continue to live in poverty and are denied a life of dignity. There are rising inequalities within and among countries. There are enormous disparities of opportunity, wealth and power. Gender inequality remains a key challenge. Unemployment, particularly youth unemployment, is a major concern. Global health threats, more frequent and intense natural disasters, spiraling conflict, violent extremism, terrorism and related humanitarian crises and forced displacement of people threaten to reverse much of the development progress made in recent decades (UN 2015, para. 14).

The United Nations Sustainable Development Goals (SDGs) report further states that:

Natural resource depletion and adverse impacts of environmental degradation, including desertification, drought, land degradation, freshwater scarcity and loss of biodiversity, add to and exacerbate the list of challenges which humanity faces. Climate change is one of the greatest challenges of our time and its adverse impacts undermine the ability of all countries to achieve sustainable development. Increases in global temperature, sea level rise, ocean acidification and other climate change impacts are seriously affecting coastal areas and low-lying coastal countries, including many least developed countries and Small Island developing States. The survival of many societies, and of the biological support systems of the planet, is at risk (UN 2015, para. 14).

Indeed, these risks reflect the strands of human security to be discussed later in this section. However, by way of background, it has to be stressed that prior to the publication of the human development report in 1990, the discourse around development, especially within the United Nations Development Programme (UNDP) had assumed a different focus. The focus prioritized a shift away from the dominant economic model, which emphasized income/expenditure as a measure of poverty, to incorporating qualitative attributes such as literacy and life expectancy, which placed the human being at the center of development (UNDP 
1994). Consequently, an important outcome of this human development concept was the shift in emphasis to human security from the traditional state-centric approach to security. Even though, leading scholars (Buzan et al. 1998; Axworthy 2001) have given an analytical framework for explaining and assessing human security, the determination by the UNDP to dedicate its 1994 annual flagship report to human security certainly increased the currency of the concept beyond a mere academic rhetoric to an approach deserving of global and national policy attention (see UNDP 1994).

However, in spite of its primary concern for the individual as opposed to the state, the concept of human security has been defined in a variety of ways. It often connotes something that is basic to the human being and must be guaranteed to ensure human survival. In other words, human security is concerned with the enjoyment of certain basic standards (minimum normative threshold) for the individual but below which the person's survival and wellbeing may be threatened (Gasper 2010). Such minimum normative thresholds may include the ability to afford basic necessities of life such as food, health, shelter, clothing, education, sanitation, and quality environment (ibid.; Alkire 2003).

In this same regard, one can also think of a maximum (optimum) normative threshold beyond which survival and wellbeing can also be threatened. For example, whereas both contentment, including the ability to be prosperous in life, and command self-actualization are thought to be desirable ends in the hierarchy of human development needs (Maslow 1954), the aspects of greed can constitute a threat to survival and wellbeing. In Africa, leading scholars contend that most armed conflicts which have spread across the continent have their roots in greed (Collier and Hoeffler 2004). Quantson's $(2010,2)$ definition of what security is makes a modest attempt to bring these different thresholds together in a conceptual framework that he describes as: survival, safety, wellbeing and contentment. Contentment, in this instance, seeks to set the 'maximum normative threshold' beyond which the exercise of one's desire could be viewed as greed-the consequences of which can be instability and insecurity as witnessed in many parts of Africa.

In similar respects, it has become common place to find the core attributes of human security described broadly as both "freedom from want" and "freedom from fear." When seen as freedom from want, human security describes a state of being in which basic material needs are met. This also translates into having a reasonable expectation for protection and affordability during crisis such that survival is not threatened. Similarly, when viewed as freedom from fear, human security depicts a condition of existence in which human dignity-especially as impacted by violent conflicts and mass atrocity crimes such as crimes against humanity, war crimes, genocide and ethnic cleansing-is preserved. Thomas, for instance, has an extended view of this strand of human security when he argues that freedom from fear should equally encompass meaningful participation in 
Table 1. Comparison between Traditional Security and Human Security

\begin{tabular}{|c|c|c|c|}
\hline & Indicator & Traditional Security & Human security \\
\hline 1 & Referent object & The state & Humanity (individuals) \\
\hline 2 & Operating principle & The state and national security & Global holism and connectivity \\
\hline 3 & Agenda & $\begin{array}{l}\text { Justification and status quo } \\
\text { Military power } \\
\text { National defence }\end{array}$ & $\begin{array}{l}\text { Explanation and transformation } \\
\text { (economic and Social welfare) }\end{array}$ \\
\hline 4 & Means & Self-help by states & $\begin{array}{l}\text { Collective, integrated, multifaceted } \\
\text { response at multiple levels }\end{array}$ \\
\hline 5 & Input & Military expenditure and arms & Redistribution, structural reform \\
\hline 6 & Output & Secure borders & $\begin{array}{l}\text { Enjoyment of economic, social, civil } \\
\text { and political and cultural human } \\
\text { rights }\end{array}$ \\
\hline 7 & Outcome & $\begin{array}{l}\text { Interstate stability } \\
\text { Order }\end{array}$ & Global social justice \\
\hline 9 & Future & $\begin{array}{l}\text { Intrastate conflict } \\
\text { International instability } \\
\text { Unsustainable resource use }\end{array}$ & $\begin{array}{l}\text { Sustainable peace } \\
\text { Sustainable development }\end{array}$ \\
\hline 10 & Attribute of Peace & Negative peace & Positive peace \\
\hline
\end{tabular}

Source: Adapted from Thomas $(2007,110)$.

development such that there is a substantive account of, for example, politics as freedom from domination or exploitation, and not simply as an exercise of freedom to choose (Thomas 2007, 108).

The specific attributes of human security when viewed from a normative perspective is illustrated in Table 1. It can be found that whereas human security envisages a perspective of positive peace because of the emphasis on global justice and structural reform, traditional security entrenches negative peace as it underscores military power as justification of stability.

Again, rather than seeing human security as a contrast opposition to traditional security, the specific attributes of human security suggest a future development path in which globalization will become the fulcrum for guaranteeing survival and wellbeing.

In spite of its major successes, especially in terms of using human rights, rule of law, treaty-based solutions and a humanitarian conception to drive humanitarian assistance, international interventions, including peacekeeping and post-conflict peacebuilding (ibid., 113), the implementation of human security, especially as freedom from fear, has often come into conflict with national interests. This is partly because of the fact that there is a certain convolution of issues that potentially risk being securitized (i.e. ordinary political issues being 
brought under traditional security) and elevated as national security concern or threat. Nonetheless, it has to be said that the need to shift focus to human security has not only helped to bridge the security-development gap, but has particularly inspired a series of reforms in political governance and security sector in Africa. Notably, it is believed that democracy remains one of the fundamental means through which human security can be achieved.

\section{Democratization, Governance, and Human Security}

The idea that democratic governance is an important prerequisite for the enjoyment of human security has somewhat been embraced by many African countries. This is evident in the so-called "third wave of democratization" which virtually swept across most parts of the developing world, including Africa. It is observed that between the 1980s and 1990s, many developing countries transitioned into democratic rule. This was a sharp contrast from the situation in the 1950s and 1960s when many countries rather had non-democratic regimes, typified variously as military, one-party, no-party and personalistic dictatorships (Haynes 2007). These types of regimes turned security into personalized protection and used the security agencies against their own populations.

In fact, some experts have put it more succinctly:

At the heart of African insecurity story is a breakdown in governance systems due in large part to rule by patronage and the associated misuse of governmental instruments of coercion to entrench political and social exclusion. At best, while maintaining a façade of viability and stability, this situation has created state repression of local population under authoritarian regimes concerned, above all, with preserving the regime rather than ensuring security of the state and its citizens. At worst, it has led to the outbreak of armed conflict and humanitarian tragedy (Bryden, N’Diaye, and Oloniskin 2008, 3).

By the year 2000, there were as many as forty-five (45) new democracies across the developing world. Of this number, Africa had eighteen (18) new democracies. Five (5) of this number were rated as "free" new democracies, and thirteen (13) were categorized as "partly free" new democracies. However, in spite of the positive democratic trend, there are ample signs that the quality of "free democratic countries" is in decline. This trend is obvious in the 2019 Freedom House report, which observes that there has been a thirteen (13) consecutive year decline in global democratic freedoms. The report suggests that:

The reversal has spanned a variety of countries in every region, from long-standing democracies like the United States to consolidated authoritarian regimes like China and Russia. The overall losses are still shallow compared with the gains of the late 20th 
century, but the pattern is consistent and ominous. Democracy is in retreat (Freedom House 2019, 1).

It is further observed that, for instance, between 1988 and 2005 the percentage of countries rated "Not Free" in democracy in the world dropped by almost 14 percent (i.e. from 37 to 23 percent), whereas the share of "Free" democratic countries increased (from 36 to 46 percent). Unfortunately, this positive trend has slowly reversed to the extent that between 2005 and 2018, the share of "Not Free" democratic countries increased to 26 percent, while the share of "Free" democratic countries declined to 44 percent. The decline in the number of free democratic countries in the world is said to be caused by violent conflicts, violent extremism, and more especially electoral violence. This is particularly so because authoritarian regimes continue to perpetuate their rule through constitutional changes which allow them to remove and extend both term and age limits. The countries which exhibited the most significant risks in free democratic processes in Africa in 2018 include Burundi, Togo, Benin, Cameroon, and Senegal (ibid.).

However, in spite of these declines, a few countries in the region were able to show considerable improvements in their free democratic credentials, following successful elections, and the opening up of their democratic space to entrench the rule of law, respect for human rights, and the determination to tackle corruption in societies where hitherto were under authoritarian rule. For instance, the countries with these significant strides include The Gambia, Angola and Ethiopia. Moreover, even in authoritarian regimes such as Cameroon, Sudan and Algeria, continuous public pressure is beginning to cause democratic change even amidst state sponsored intimidation, security crackdown and repression of citizens.

Table 2. Regional Outlook of Free Democratic Practice

\begin{tabular}{|c|c|c|c|c|c|c|c|c|c|c|c|c|c|c|}
\hline \multirow{3}{*}{ Category } & \multicolumn{12}{|c|}{ Regional Distribution } & \multirow{2}{*}{\multicolumn{2}{|c|}{ Total }} \\
\hline & \multicolumn{2}{|c|}{$\begin{array}{c}\text { Sub- } \\
\text { Saharan } \\
\text { Africa }\end{array}$} & \multicolumn{2}{|c|}{ Americas } & \multicolumn{2}{|c|}{ Asia Pacific } & \multicolumn{2}{|c|}{ MENA } & \multicolumn{2}{|c|}{ Euroasia } & \multicolumn{2}{|c|}{ Europe } & & \\
\hline & C'try & Pop. & C'try & Pop. & C’try & Pop. & C'try & Pop. & C’try & Pop. & C'try & Pop. & C'try & Pop. \\
\hline Free $(\%)$ & 18 & 11 & 66 & 69 & 46 & 39 & 11 & 4 & & & 81 & 83 & 44 & 39 \\
\hline $\begin{array}{l}\text { Partly Free } \\
(\%)\end{array}$ & 43 & 50 & 26 & 26 & 33 & 21 & 22 & 13 & 42 & 20 & 17 & 4 & 30 & 24 \\
\hline $\begin{array}{l}\text { Not Free } \\
(\%)\end{array}$ & 39 & 39 & 8 & 5 & 21 & 40 & 67 & 83 & 58 & 80 & 2 & 13 & 26 & 37 \\
\hline Population & $\begin{array}{r}1 . \\
\text { Billi }\end{array}$ & $\begin{array}{l}1 \\
\text { ion }\end{array}$ & $\begin{array}{r}1 \\
\text { Bill }\end{array}$ & $\begin{array}{l}1 \\
\text { lion }\end{array}$ & $\begin{array}{r}4 \\
\text { Bill }\end{array}$ & $\begin{array}{l}1 \\
\text { ion }\end{array}$ & $\begin{array}{r}442 \\
\text { Mill }\end{array}$ & & $\begin{array}{r}29 \\
\text { Mill }\end{array}$ & $\begin{array}{l}1.8 \\
\text { ion }\end{array}$ & & $\begin{array}{l}5.1 \\
\text { lion }\end{array}$ & $\begin{array}{r}7 . \\
\text { Bill }\end{array}$ & \\
\hline Countries & 45 & & 3 & 5 & 3 & & 18 & & 1 & & 4 & 2 & 19 & 5 \\
\hline
\end{tabular}

Source: Extracted from Freedom House report (2019). 
However, most certainly, such trends are deemed to inspire citizens desire for freedom from political dictatorship (ibid.).

Knowing that Africa (and for that matter, sub-Saharan Africa) is greatly influenced by global political events and trends, a discussion of its free democratic practice will make greater meaning if other countries and regions are brought in view of the discussion. As illustrated in Table 2, of the forty-nine (49) countries studied in sub-Saharan Africa, only 18 percent (representing only nine countries) were rated as free democratic states. This contrasts somewhat significantly with the global average of 44 percent. It also represents a large deficit as compared with the Americas and Europe, which were rated 66 percent and 81 percent respectively. Sub-Saharan Africa only performed better than Middle East and Northern Africa (MENA) and Euroasia where, currently, there are severe political crisis (involving activities of violent extremists and fragile political regimes) which has engulfed countries like Syria, Yemen, Iraq, Afghanistan, and Libya. In terms of the share of population who enjoys free democratic expressions of the rule of law and human rights, sub-Saharan Africa with estimated total population figure of 1.1 billion, had only 11 percent of its population being free. This again represents a large deficit from the global average of 39 percent, and is also a far cry from what obtains in countries in Asia Pacific, Americas and Europe which were rated 39 percent, 69 percent and 83 percent respectively; interestingly, the contrast between Africa and the rest of the regions would have been sharper had North African countries (presently captured in MENA) been included in the African statistics.

It is unsurprising that distressed populations-mainly the youth, women and children-from the least free democratic countries continue to suffer the risk of human trafficking and irregular migration ostensibly to seek haven in the so-called free democratic countries. Table 2 also shows that, while twentyone (21) African countries (representing 43 percent) are classified as partly free democratic states, a significant proportion (50 percent) of its population still experience substantial limitations to freely express their democratic and human rights. More so, additional 39 percent of its population is said to endure no free democratic choices. Thus, it appears that while political regimes may enjoy the façade of being "strong" and "stable", there is a gradual erosion (underneath that façade) of human security of the populations in Africa.

It has to be seen that, in spite of the foregoing observations, it is not uncommon to find African governments cast misgivings over analysis on African democratic governance based on data sources generated from Western-based think tanks, or local civil society organizations that receive funding support from Western partners. Such misgivings may be borne out of a genuine need to question underlining assumptions, methodology and other political agendas, which may be hidden in such Western-driven analysis and reports. Similarly, it could also be based on mere refusal to admit weaknesses in adhering to 
good governance principles as has often been the case in Africa. As a result, data sources which may have a Pan-African outlook such as the Ibrahim Index of African Governance (IIAG) may have some greater appeal to most African governments. The next section discusses African human security issues based on the 2018 IIAG.

Defined based on generic governance criteria, human security is described in terms of the quality of being in a variety of core qualitative variables such as (1) safety and rule of law; (2) participation and human rights; (3) sustainable economic opportunity; and, (4) human development. Since 2007, these core human security standards have been evaluated and rated across Africa to show how countries compare with their own peers in the region as opposed to countries from outside the African region.

In 2017, Africa had an overall average governance score of just about 50 percent. This represents a "slowing improvement" because it recorded just a marginal cumulative change of $(+1)$ since 2008. This means that Africa has not seen any significant change in its overall human security situation since 2008. However, there were slightly higher scores in the categories of safety and rule of law (52.6 percent) and human development (52.8 percent). The remaining two categories: participation and human rights ( 49.2 percent) and sustainable economic opportunity (44.8 percent) both scored below the overall average in the region. Again, in terms of the cumulative change over the period between 2008 and 2017, Africans enjoyed slight improvements in the area of participation and human rights $(+2.9)$, sustainable economic opportunity $(+0.1)$, and human development (+3.5). However, in spite of its 52.6 percent score in 2017, safety and rule of law plummeted by -2.5 in the cumulative period between 2008 and 2017. This means that while Africans are steadily enjoying improvements in the human development indicators, the population has become worse off in terms of safety and rule of law within the last decade.

Further, within the last decade, the 2018 IIAG report observes that whereas there were as many as thirty-four (34) African countries with improvements in their governance performance, eighteen (18) countries actually experienced deteriorated conditions in the quality of their governance (which also, almost invariably, translates to a decline in the quality of their human security). One country did not experience any change in its governance conditions over the 10year period. The report further highlights that of the thirty-four (34) countries which experienced improvements in their governance processes, only fifteen (15) countries experienced "increasing improvement," while thirteen (13) countries experienced "slowing improvement." The remaining seven (7) countries are noted as showing "slowing decline" in their governance processes. Six (6) countries are deemed to be bouncing back to favorable governance conditions from their previous deterioration position within the last ten years. As many as twelve (12) countries have experienced "increasing deterioration." More so, whereas Libya 
Table 3a. Top 10 and Bottom 10 Governance Performance in Africa

\begin{tabular}{l|l|c|c|l}
\hline \hline \multirow{2}{*}{ Rank/54 } & \multirow{2}{*}{ Country } & $\begin{array}{c}2017 \\
\text { score/100 }\end{array}$ & \multicolumn{2}{|c}{ Performance over last 10 years } \\
\cline { 4 - 5 } & & 79.5 & $(-0.7)$ & \multicolumn{1}{|c}{ Classification } \\
\hline 1st & Mauritius & 73.2 & $(+4.0)$ & Increasing deterioration \\
\hline 2nd & Seychelles & 71.1 & $(-0.8)$ & Increasing improvement \\
\hline 3rd & Cabo Verde & 68.6 & $(+3.3)$ & Slowing improvement \\
\hline 4th & Namibia & 68.5 & $(-3.7)$ & Increasing deterioration \\
\hline 5th & Botswana & 68.1 & $(+0.9)$ & Increasing improvement \\
\hline 6th & Ghana & 68.0 & $(-0.6)$ & Bouncing back \\
\hline 7th & South Africa & 64.3 & $(+5.9)$ & Slowing improvement \\
\hline 8th & Rwanda & 63.5 & $(+6.9)$ & Slowing improvement \\
\hline 9th & Tunisia & 63.3 & $(+5.9)$ & Slowing improvement \\
\hline 10th & Senegal & 49.9 & $(+1.0)$ & Slowing improvement \\
\hline African Average &
\end{tabular}

Source: Extracted from IIAG report (2018).

experienced the greatest deterioration level (-15.6) in its governance architecture and processes, Cote d'Ivoire showed the greatest improvement level of $(+12.7)$ in Africa. Table 3 shows how the top ten and bottom ten countries have performed in their governance processes in 2017.

The top ten statistics in Table 3 a shows a great deal of variability in the respective governance performances over the last ten years. Only two (2) countries (Seychelles and Ghana) experienced "increasing improvement" in their governance processes. As many as four (4) countries, namely Namibia, Rwanda, Tunisia, and Senegal merely showed "slowing improvement." Moreover, whereas one (1) country (South Africa) is "bouncing back" from its previous deteriorating trajectory, as many as three (3) countries, namely Mauritius, Cabo Verde and Botswana are already showing signs of "increasing deterioration" in their human security standards. Thus far, even though a country's position on the ranking may suggest improved political governance at current level, the variability in the governance indicators over a period, however, serves as critical pointers as to whether a country is backsliding or entrenching political governance.

From Table $3 \mathrm{~b}$, the bottom ten countries also show similar variations in their governance performance as was amply seen in the top ten (10) analysis in Table 3a. Apart from countries such as Democratic Republic of Congo (DRC), Equatorial Guinea, and Libya, which continue to deteriorate at an increasing pace in their political governance processes, all the other countries in the 
Table 3b. Top 10 and Bottom 10 Governance Performance in Africa

\begin{tabular}{|c|c|c|c|c|}
\hline \multicolumn{5}{|c|}{ Bottom 10 Countries } \\
\hline \multirow{2}{*}{ Rank/54 } & \multirow{2}{*}{ Country } & \multirow{2}{*}{$\begin{array}{c}2017 \\
\text { score/100 }\end{array}$} & \multicolumn{2}{|c|}{ Performance over last 10 years } \\
\hline & & & Change (2008-2017) & Classification \\
\hline 45 th & Angola & 38.3 & $(+0.7)$ & Warning sign \\
\hline 46 th & Chad & 35.4 & $(+4.6)$ & Slowing improvement \\
\hline 47 th & DRC & 32.1 & $(-2.8)$ & Increasing deterioration \\
\hline 48th & Equatorial Guinea & 30.9 & $(-0.1)$ & Increasing deterioration \\
\hline 49th & Sudan & 30.8 & $(+1.4)$ & Increasing improvement \\
\hline 50 th & CAR & 29.5 & $(-2.5)$ & Bouncing back \\
\hline 51 st & Eritrea & 29.3 & $(-2.9)$ & Bouncing back \\
\hline 52 nd & Libya & 28.3 & $(-15.6)$ & Increasing deterioration \\
\hline $53 \mathrm{rd}$ & South Sudan & 19.3 & $\mathrm{X}$ & $\mathrm{X}$ \\
\hline 54th & Somalia & 13.6 & $(+6.0)$ & Increasing improvement \\
\hline \multicolumn{2}{|c|}{ African Average } & 49.9 & $(+1.0)$ & Slowing improvement \\
\hline
\end{tabular}

Source: Extracted from IIAG report (2018).

league have shown signs of reversing their deteriorating trend over the last ten years. However, in spite of this positive highlight, it can be seen that majority of populations in this league enjoy less human security as they constantly experience a mixture of conflicts, violence, violent extremism, intimidation, and repressive political regimes. Thus, it can be observed that irrespective of a county's position in the governance index, there is still the potential risk of declining if reforms are not carried out in the security sector.

\section{Security Sector Reform and Governance in Africa}

It will be an exercise in futility to have democracy in Africa without a corresponding reform of the security sector. Indeed, if African citizens are to enjoy freedom from fear of regime repression, brutality, armed conflicts and violence, then a different approach (i.e. a human security approach) to the ways in which security sector institutions operate should be of prime interest. This calls for dynamic civil-military (security) engagements with human rights and the rule of law (rather than brute force) being the driving force behind security architectures and policies in Africa. Reversals and/or backsliding in democracy and the rule of law in Africa are partly attributed to a lack of security sector reform (Houngnikpo 2012). The human security approach to security sector operations and delivery 
requires a shift to democratic rule, where security forces are expected to operate within a democratic culture (Aning 2008). This is essentially because, as some other scholars have argued, a safe and secure environment tends to promote economic and political development. As such, countries with weak governance systems are seen to risk higher rates of impunity by security forces, making both the state and citizens less secured (Ball 2014).

Broadly speaking, security sector reform (SSR) deals with creating a nationally owned process to promote the effective and efficient provision of security and justice in accordance with citizens' needs, representing a system wherein security and justice providers are accountable to the state and its people, and operates within a framework of democratic governance, rule of law, and respect for human rights (OEDC DAC 2005; Aning 2008). So far, the forgoing discussions have shown how African countries and populations have fared under the prevailing attributes of democratic governance, rule of law and human rights-all critical components of SSR. Measurements based on these attributes have shown variability in performance across time, countries and regions. However, in spite of the current favorable ranking by, for example the IIAG, even occupants of the top ten category still exhibit signs of deterioration in their governance and human security processes over the last ten years. It is argued that part of the ways to reverse the deteriorating trend in Africa is to reorient the security forces to make them more effective, efficient, accountable and transparent (Aning and Lartey 2009; Djindjere 2010).

In the region, even though the SSR effort is still deemed to be an ongoing process, the attempt at introducing the core principles of effectiveness, efficiency, accountability and transparency in the security sector has produced mixed results so far. This is partly because of one main reason: there has been over concentration of effort on training and equipping of security forces without incorporating the dimensions of accountability and transparency. This approach has led to lopsided results in most SSR programs in Africa. This is especially so because of the desperate need to build strong capabilities for the security forces to be able to deal with threats of internal insurrection, terrorism, violent extremism, and transnational organized crimes such as drug trafficking, arms trafficking and piracy. It is thought that these threats require continues training and equipping of the state security forces in order to make them effective. Meanwhile, there are deficits of human rights and the rule of law which underpin provision of security in conflict and violent extremism contexts. Countries such as Somalia, South Sudan, Burundi, DRC, Guinea Bissau, Uganda, Rwanda, and Mali have had their security sector reforms geared more or less in this direction" of operational strengthening" (Bryden and Olonisakin 2010).

The increasing escalation in violent extremism in the Sahel region, has brought about initiatives such as the G5 Sahel, comprising Burkina Faso, Chad, Niger, Mali and Mauritania. This is largely a military capability-not the least 
aimed at reforming security institutions-but rather focused more on countering the violent extremist elements that are generating insecurity for the population in the Sahel region. Similarly, the Multinational Joint Taskforce (MNJTF), including the military from Benin, Cameroon, Chad, Niger and Nigeria, designed to counter the Boko Haram insurgency in the Lake Chad Basin is also aimed at operational strengthening as opposed to governance strengthening of the security forces. Beside the human rights abuses and violations reportedly being committed against ordinary civilians and prisoners by the security forces involved in these operations (see Human Rights Watch 2015), steps should be taken to avoid the risks of regimes and personnel visiting or extending such human rights violations to their own citizens after exiting these operations. A continuous security sector reform process, especially focusing on the accountability and transparency aspects will be required to recreate the needed 'concordance' (Schiff 2009) between the civilians and security forces who are entangled in this conflict system (Diallo 2009).

Nonetheless, as part of the security sector reform process, the idea of 'democratic policing,' which calls for more accountability and transparency in the delivery of security has been given some close attention in Africa. Even though, the process is being undermined by the recent escalation of violent extremism, there are still areas where some success has been achieved. For instance, drawn from the need to incorporate customer service philosophy into the work of the security sector, community policing has been introduced as part of the SSR process to improve the quality of the police service and customer satisfaction. This fundamentally, involves greater working relationship between the police and the public (Bannet 1994). The concept has been deployed both as a philosophy and organizational strategy in post-conflict countries such as Sierra Leone and Liberia. Notably, platforms such as "local police partnership boards" in Sierra Leone (Gbla 2018, 10) and the county security committees in Liberia (Jaye 2008) have enabled community members and police to team up in new ways to address issues of crime, violence, domestic and gender-based violence, and land and chieftaincy disputes (Jaye 2018). In some instances, Tilley (2008, 376) contends that community policing had been integrated in the structure of the police organization, employing community policing officers, adopting a proactive approach, engaging in problem-solving with community members, and other agencies, and adopting decentralized ways of working. For instance, in both Liberia and Sierra Leone, it was partly this sort of community-security partnership arrangements that enabled the country to overcome the Ebola virus crisis in 2014, and particularly much so in Sierra Leone during the mudslide disaster in 2017 (Gbla 2018).

Across board, the security policy space in Africa still portrays a regimecentric posture. While new constitutions have emerged, the frequent violent and irregular assaults on these new constitutions (either through military 
interference or executive manipulations) have led to the weakening of other state institutions such as the legislature, judiciary, and even civil society. Most security legislations are not aligned with current democratic tenets. They still reflect the colonial and autocratic tendencies, which emphasized repression as opposed to protection of citizens (Houngnikpo 2012). To fully embrace, human security in Africa, countries must begin to develop broad-based national security policy and strategy which incorporates the human security needs of the population. Such policies will determine which security issues should be prioritized and with what resource allocation and accountability.

Another evidence of regime-centered security in Africa relates to the architectures of national security, where almost all the members constituting the national security architecture are party appointees, and even when they represent their security institutions, professionalism is sacrificed for patronage biases (Houngnikpo 2012). By this composition, there is a high risk of the national security council members aligning loyalties with the personal interest of the appointing authority (which is often the Commander-in-Chief or the president) (see Bryden, N'Diaye, and Oloniskin 2008, 3; Houngnikpo 2012). Kondeh (2008) explains further that presidents in Africa wield tremendous powers, allowing autocratic and despotic leaders to appoint people not on the basis of professional competence but on their personal and partisan loyalty. This reinforces regime security as opposed to national security. The resultant effect is the perpetuation of repressive rule, which ultimately threatens the enjoyment of human security in Africa. Even with the limited chance of political turnover experiences in countries such as Ghana, Senegal, Liberia, Sierra Leone, and Nigeria, it does seem that each turnover is viewed by both incumbent and opposition parties as "regime overthrow," which rather impedes smooth transition of political power after elections in Africa.

\section{Conclusion}

Based on generic governance criteria, human security is described in terms of the quality of being in a variety of core qualitative variables such as (1) safety and rule of law; (2) participation and human rights; (3) sustainable economic opportunity; and, (4) human development. Within the last decade, these core human security standards have been evaluated and rated across Africa to show how countries compare with their own peers in the region. It was observed that while some countries such Seychelles and Ghana have shown increasing improvement only a marginal improvement was recorded in the overall position of human security in Africa. Indeed, other countries such as Mauritius and Cabo Verde, even though enjoy the ranks of the top ten governance category, have started showing signs of increasing deterioration over the last decade. 
Importantly, however, African countries have had an iterative transition toward the concept of human security. This is partly because of the "insecurity dilemma" (i.e. the fear that regime security will provoke and escalate violent contests from internal spheres) which stems from the cycle of political instability and autocratic rule in the region. Often, citizen's needs and interests do not find expression in political settings where human rights and the rule of law are absent and/or inadequate. In Africa, adherence to the rule of law and respect for human rights appear to be a natural struggle for most governments. This is because the pursuit of regime security while maintaining respect for human rights and the rule of law appears incompatible in their governance perspectives. While democracy seeks to overcome this challenge, the continent still finds itself embroiled in an era of violent extremism and terrorism, producing a different kind of security dynamics that emphasizes operational strengthening of the security forces rather than a focus on security sector governance.

Nevertheless, given the tortuous approach to the free democratic process and the fragile prosecution of the rule of law in Africa, the achievement of human security seems far from reach, not least in the immediate-medium term. Indeed, the abovementioned statistics of Africa currently posting only nine (9) countries (i.e. 18 percent) - which also translates to only 11 percent of its citizens being freely democratic-lends credence to the difficulty in expending and deepening the human security concept and practice on the continent. There are still about forty (40) countries in Africa whose free democratic conditions remain fragile, while over 80 percent of the citizens still live under political regimes, which are experiencing conflicts or political crises or violent extremism or repressive security forces. This is in spite of the democratic spread, which accompanied the so-called "third wave of democratization" in Africa in the early 1990s. Security sector reform must be given a new focus away from the traditional approach of operational strengthening to the building of institutions that will strengthen accountability and transparency in the security sector.

\section{References}

Alkire, Sabina. 2003. "A Conceptual Framework for Human Security." Working Paper 2, Centre for Research on Inequality, Human Security and Ethnicity. CRISE: University of Oxford.

Aning, Kwesi. 2008. "Ghana." In Parliamentary Oversight of the Security Sector in West Africa, eds. Adedeji Ebo and Boubacar N'Diaye. Geneva: DCAF.

Aning, Kwesi, and Festus Aubyn, 2018. "Challenging Conventional Understandings of Statehood: West African Realities." In Exploring Peace Formation: Security and Justice in Post-Colonial States, eds. Aning Kwesi, Boege Volker, Brown M. Anne, and Hunt T. Charles. New York: Routledge, 24-38.

Aning, Kwesi, and Ernest Lartey. 2009. Parliamentary Oversight of the Security Sector: 
Lessons from Ghana. New York: Center on International Cooperation.

Axworthy, L. 2001. "Human Security and Global Governance: Putting People First." Global Governance 7 (1), January/March, 19-23.

Ball, Nicole. 2014. "Lessons from Burundi’s Security Sector Reform Process." African Security Brief 29 (November). African Centre for Strategic Studies.

Bannet, T. 1994. "Community Policing on the Ground: Development in Britain." In The Challenge of Community Policing, ed. D. Rosenbaum. Thousand Oaks, CA: Sage, 22446.

Bryden, Alan, and Fairlie Chappuis. 2015. "Introduction: Understanding Security Sector Governance Dynamics in West Africa." In Learning from West African Experiences in Security Sector Governance, eds. Alan Bryden and Fairlie Chappuis. London: Ubiquity Press, 1-18.

Bryden, Alan, Boubacar N'Diaye, and Funmi Oloniskin, eds. 2008. "Understanding the Challenges of Security Sector Reform in West Africa." In Challenges of Security Sector Governance in West Africa. Geneva: DCAF, 3-24.

Bryden, Alan, and Funmi Olonisakin. 2010. "Enabling Security Sector Transformation in Africa." In Security Sector Transformation in Africa, eds. Alan Bryden and Funmi Olonisakin. Geneva: DCAF, 291-20.

Buzan, B., O. Waever, and J. de Wilde, eds. 1998. Security: A New Framework for Analysis. Boulder, Colorado: Lynne Rienner.

Cheru, Fantu. 2007. "The Heavily Indebted Poor Countries (HIPC) Initiative: Old Wine in a New Bottle?” In Globalisation, Development and Human Security, eds. McGrew Anthony and Nana K. Poku. Cambridge: Polity Press, 66-82.

Civic, Melanne A., and Miklaucic Michael. 2011. "The State and the Use of Force; Monopoly and Legitimacy." In Monopoly of Force: The Nexus of DDR and SSR, eds. Melanne A. Civic and Miklaucic Michael. Washington, DC: National Defense University Press, xi-xxi.

Collier, Paul, and Anke Hoeffler. 2004. "Greed and Grievance in Civil Wars." Oxford Economic Papers 56 (4): 563-95.

Diallo, Massaer. 2009. Conflict System in West Africa. Paris: OECD.

Djindjere, Dominique. 2010. "Democracy and Chain of Command: A New Governance of Africa’s Security Sector." African Security Brief. No. 8; November. African Centre for Strategic Studies.

Freedom House. 2019. “Freedom in the World 2019.” Washington, USA: Freedom House.

Gasper, Des. 2010. "The Idea of Human Security." In Climate Change, Ethics and Human Security, eds. K. O’Brien, A. L. St. Clair, and B. Kristoffersen. Cambridge: Cambridge Univ. Press, 23-46.

Gbla, Osman. 2018. "Hybrid Security Governance Responses to Crises: The Case of the Ebola Response in Sierra Leone. Stability." International Journal of Security \& Development 7 (1): 8, 1-11.

Haynes, Jeff. 2006. “The Principles of Good Governance." In Managing Defence in a Democracy, eds. R. Laura Cleary and Teri McConville. New York: Routledge, 17-31.

Haynes, Jeffrey. 2007. “Globalisation and Democracy in the Developing World.” In Globalisation, Development and Human Security, eds. Anthony McGrew and Nana K. Poku. United Kingdom: Polity Press, 83-104.

Houngnikpo, Mathurin C. 2012. Africa's Militaries: A Missing Link in Democratic 
Transitions. Washington, DC: African Centre for Strategic Studies.

Human Rights Watch. 2015. "West Africa: Regional Boko Haram Offensive: Multinational Effort Should Protect Civilians, Respect Prisoner Rights." https://www.hrw.org/ news/2015/02/11/west-africa-regional-boko-haram-offensive (accessed March 2, 2019).

IIAG. 2018. Index Report. Mo Ibrahim Foundation. http://s.mo.ibrahim.foundation/ u/2018/11/27173840/2018-Index-Report.pdf (accessed March 2, 2019).

Jackson, Richard. 2007. “Regime Security.” In Contemporary Security Studies, ed. Alan Collins. New York: Oxford University Press, 146-63.

Jaye, Thomas. 2008. "Liberia’s Security Sector Legislation." Geneva: Centre for the Democratic Control of Armed Forces (DCAF).

Jaye, Thomas. 2018. "Understanding and Explaining Hybridity in Liberia." In Globalisation, Development and Human Security, eds. Anthony McGrew and Nana K. Poku. United Kingdom: Polity Press, 83-104.

Kondeh, Al-Hassan. 2008. "Sierra Leone." In Challenges of Security Sector Governance in West Africa, eds. Alan Bryden, Boubacar N’Diaye, and Funmi Oloniskin. Geneva: DCAF, 3-24.

Luckham, Robin. 2003. "Democratic Strategies for Security in Transition and Conflict." In Governing Insecurity: Democratic Control of Military and Security Establishment in Transitional Democracies, eds. Gavin Cawthra and Robin Luckham. London and New York: Zed Books Ltd., 3-28.

Maslow, Abraham Harold. 1954. Motivation and Personality. NY: Harper.

M'Cormack-Hale, Fredline. 2018. "Prospects for Accessing Justice for Sexual Violence in Liberia's Hybrid System.” Stability: International Journal of Security \& Development, 7 (1): 10, 1-16.

Ndiaye, Boubacar. 2010. "Conflicts and Crises: Internal and External Dimensions." In ECOWAS and the Dynamics of Conflict and Peacebuilding, eds. Jaye Thomas and Amadi Stella. Dakar, Senegal: CODESRIA, 38-58.

OEDC DAC (Development Assistance Committee of the Organisation for Economic Cooperation and Development). 2005. Handbook on Security System Reform (SSR): Supporting Security and Justice. Paris: OECD.

Paris, Roland. 2001. "Human Security: Paradigm Shift or Hot Air?" International Security 26 (2): 87-102.

Quantson, Kofi B. 2010. You and Your Security Environment. Accra: Napasvil Ventures.

Schiff, Rebecca. 2009. The Military and Domestic Politics: A Concordance Theory of CivilMilitary Relations. London: Routledge.

Thomas, Caroline. 2007. "Globalisation and Human Security." In Globalisation, Development and Human Security, eds. Anthony McGrew and Nana K. Poku. United Kingdom: Polity Press, 107-31.

Tilley, Nick. 2008. "Modern Approaches to Policing: Community, Problem-Oriented and Intelligence-Led." In Handbook of Policing, ed. Tim Newburn. UK: Willian Publishing, 373-403.

UN (United Nations). 2015. “Transforming Our World: The 2030 Agenda for Sustainable Development." A/RES/70/1.

UNDP (United Nations Development Programme). 1994. "Human Development Report." Oxford: Oxford University Press. 
Kwesi Aning (PhD) is the Director of the Faculty of Academic Affairs and Research (FAAR) of the Kofi Annan International Peacekeeping Training Centre (KAIPTC) in Accra, Ghana. His rich experience in African security issues has been tapped by a number of organizations, including the United Nations, African Union and the Economic Community of West African States where he has held high-level leadership positions. Kwesi has written several publications on peace and security in Africa. Email: Kwesi.Aning@Kaiptc.org.

Ernest Ansah Lartey is a researcher and the Head of the Peace and Security Studies at the Faculty of Academic Affairs and Research (FAAR) of the Kofi Annan International Peacekeeping Training Centre (KAIPTC) in Accra, Ghana. His research interests include security sector reform, peacebuilding, and elections. He has published several papers relating to these research interests. Email: Ernest.Lartey@Kaiptc.org.

Submitted: July 24, 2019; Revised: October 30, 2019; Accepted: November 1, 2019 
